\title{
CHEMICAL ANALYSES OF TWO PATHOLOGICAL HUMAN BRAINS.
}

By C. G. MacARThUR and E. A. DOISY,

The Biochemical Department of the University of Illinois and the Pharmacological Department of Stanford Medical School.

Though the literature ${ }^{1-8}$ contains some information about the chemical changes occurring in brain disease, it seems justifiable to continue this work. By dividing the brain into three divisionscerebrum, cerebellum, and brain stem (including medulla, pons, midbrain and thalami) the localization of the brain alterations could be partially determined. In later work the number of brain divisions is being increased, to get a clearer idea of the smaller changes in chemical constitution.

\section{Case Histories.}

The brain marked "Path. K." was obtained from the State Psychopathic Institute and Hospital of Kankakee, Illinois, through the kindness of $\mathrm{H}$. Douglas Singer. It was sent to Urbana, Illinois, on the day it was removed from the cranium. The patient had been at the institute nearly two months. Evidences of mental disorganization were well marked. The immediate cause of death was pneumonia. The diagnosis was paresis.

The brain marked "Path. A." was sent to Urbana, Illinois, from the Anna State Hospital at Anna, Illinois. The coroner reported apoplexy as the cause of death. Clinical diagnosis of the case reported organic brain disease, probably bulbar paralysis, because of paralysis of larynx and pharangeal disturbance. Syphilis was originally present. He had had a paralytic attack. Speech defects were marked. Pupils were asymmetric. Hallucinations and defective memory were the principal mental symptoms. He had been twice admitted to the institution. 
Method of Analysis.

The method of analysis was the same as that used for the growth series recently reported. The procedure was essentially that previously used by others on brain analysis.* The main points in the analysis are as follows: A weighed sample is placed in a bottle containing enough alcohol to make the concentration of the alcohol 85 per cent, including the water of the tissue. After standing a few weeks to coagulate the proteins, the contents are poured through an extraction cup lined with filter paper. The contents are extracted thoroughly with alcohol and ether. These extracts are added to the original alcohol used for coagulation. After removal of the organic solvents by heat, an emulsion is made in water. The lipins are precipitated by hydrochloric acid and chloroform. Thus the material is separated into three large fractions-a protein residue, the lipins, and extractives. A rough separation of extractives into organic and inorganic can be obtained. On each of these four groups, sulphur and phosphorus and other determinations are made. After hydrolysis of a portion of the lipin fraction, sugar was estimated. From these various determinations and the weights of the original fractions, the data of the tables have been obtained.

Owing to the delays caused by graduation exercises and room alterations, the phosphatids, cholesterol and extractives in analyses 9 and 10 and a few of the phosphorus determinations in analyses 26 and 29 have not the validity the rest of the determinations have. By check analyses it was shown that the brain marked "normal, 35 yrs." was probably normal, but not an average brain. Both of these points are considered in drawing conclusions from the data.

* Details of the method as well as the nature and significance of the various chemical compounds included in the various fractions can be found in the following articles:

Koch, W.: J. Am. Chem. Soc., 31, 1340 (1909).

Koch, M. L., and Voegtlin, C.: Hygienic Bull. 103 (1916).

MacArthur, C., and Doisy, E. A.: Human Growth Series, Journal of Comparative Neurology, August (1919). 
CEREBRUM : CONSTITUENTS IN PERCENTAGES OF FRESH TISSUE.

\begin{tabular}{|c|c|c|c|c|c|}
\hline Water $\ldots \ldots \ldots \ldots$. & $\begin{array}{c}\text { Path. K, } \\
\text { 51 yrs. } \\
\text { (5) } \\
76.51\end{array}$ & $\begin{array}{c}\text { Path. A, } \\
\text { 50 y rs. } \\
\text { (6) } \\
78.26\end{array}$ & $\begin{array}{c}\text { Normal, } \\
67 \text { y r8. } \\
\text { (22) } \\
78.47\end{array}$ & $\begin{array}{c}\text { Normal, } \\
\text { 35 yrs. } \\
(3) \\
72.85\end{array}$ & $\begin{array}{c}\text { Normal, } \\
33 \text { yrs. } \\
\text { (28) } \\
77.06\end{array}$ \\
\hline Solids.......... & 23.49 & 21.74 & 21.53 & 27.15 & 22.94 \\
\hline Phosphatids $\ldots$. & 4.84 & 4.96 & 6.54 & 6.86 & 6.00 \\
\hline Cerebrosides ..... & .44 & .75 & 1.72 & 2.58 & 1.28 \\
\hline Sulphatids $\ldots \ldots$. & 1.03 & .75 & 1.35 & 1.72 & .66 \\
\hline Cholesterol ....... & 5.00 & 4.52 & 2.55 & 4.08 & $4.8 \mathrm{I}$ \\
\hline Total lipins ......... & II.30 & 10.98 & 12.15 & 15.23 & 12.75 \\
\hline Total proteins ....... & $8.8 \mathrm{I}$ & 7.80 & 7.53 & 8.99 & 8.11 \\
\hline Org. extractives.. & 2.09 & I.70 & .88 & 2.03 & I.II \\
\hline Inorg. extractives. & 1.29 & 1.26 & .96 & .91 & .96 \\
\hline Total extractives..... & 3.38 & 2.96 & 1.84 & 2.94 & 2.07 \\
\hline Lipin sulphur ... & .021 & .015 & .027 & .034 & .013 \\
\hline Protein sulphur.. & .070 & .070 & $.06 \mathrm{I}$ & .039 & .052 \\
\hline Neutral sulphur.. & .014 & .015 & .015 & .022 & .007 \\
\hline Inorg. sulphur... & .008 & .006 & .003 & .009 & .003 \\
\hline Total sulphur........ & .113 & .106 & .106 & .104 & .075 \\
\hline Lipin phosphorus. & .208 & .207 & 254 & .300 & .234 \\
\hline Protein phos..... & .014 & $.01 \mathrm{I}$ & .012 & .014 & .011 \\
\hline Org. phosphorus. & .078 & .062 & .008 & .049 & .027 \\
\hline Inorg. phosphorus & .037 & .049 & .053 & .048 & .091 \\
\hline Total phosphorus..... & .337 & .330 & .327 & .411 & .363 \\
\hline
\end{tabular}

CEREBRUM : CONSTITUENTS IN PERCENTAGES OF SOLIDS.

\begin{tabular}{|c|c|c|c|c|c|}
\hline & $\begin{array}{c}\text { Path. K, } \\
\text { 51 yrs. } \\
\text { (5) }\end{array}$ & $\begin{array}{l}\text { Patb. A, } \\
\text { 50 yrs. } \\
\text { (6) }\end{array}$ & $\begin{array}{c}\text { Normal, } \\
67 \text { yrs. } \\
(22)\end{array}$ & $\begin{array}{c}\text { Normal, } \\
35 \text { yrs. } \\
(3)\end{array}$ & $\begin{array}{l}\text { Normal, } \\
33 \text { yrs. } \\
\text { (28) }\end{array}$ \\
\hline Phosphatids ..... & 20.64 & 22.83 & 27.19 & 25.26 & 24.67 \\
\hline Cerebrosides & 1.85 & 3.43 & 8.00 & 9.50 & 5.59 \\
\hline Sulphatids ..... & 4.39 & 3.46 & 6.26 & 6.32 & 2.89 \\
\hline Cholesterol ....... & 21.25 & 20.80 & 15.03 & 15.01 & 22.45 \\
\hline al lipins ..... & 48.13 & 50.52 & 56.48 & 56.09 & 55.60 \\
\hline al proteins ...... & 37.49 & 35.86 & 34.97 & 33.10 & 35.36 \\
\hline Org. extractives.. & 8.89 & 7.80 & 4.08 & 7.46 & 4.85 \\
\hline Inorg. extractives. & 5.49 & 5.83 & 4.47 & 3.35 & 4.19 \\
\hline al extractives..... & 14.38 & 13.62 & 8.55 & $10.8 \mathrm{I}$ & 9.04 \\
\hline Lipin sulphur.... & .088 & .069 & .125 & .127 & .058 \\
\hline Protein sulphur.. & .301 & .323 & 279 & .146 & .225 \\
\hline Neutral sulphur. . & .062 & .068 & .070 & .081 & .029 \\
\hline Inorg. sulphur... & .036 & .029 & .015 & .032 & .015 \\
\hline al sulphur........ & .487 & .489 & .489 & .386 & .327 \\
\hline Lipin phosphorus & .889 & .954 & 1.179 & 1.110 & 1.017 \\
\hline Protein phos..... & $.06 \mathrm{I}$ & .052 & .057 & .052 & .048 \\
\hline Org. phosphorus. & .334 & .288 & .035 & .180 & .117 \\
\hline Inorg. phosphorus & .157 & .226 & .244 & .172 & .394 \\
\hline al phosphorus.... & $1.44 \mathrm{I}$ & 1.520 & 1.515 & 1.515 & 1.576 \\
\hline
\end{tabular}




\begin{tabular}{|c|c|c|c|c|c|}
\hline \multirow[t]{2}{*}{ CEREBRUM : } & \multirow{2}{*}{$\begin{array}{c}\text { WEIGHT } \\
\text { Path. K, } \\
\text { St yrs. } \\
\text { (5) }\end{array}$} & \multicolumn{4}{|c|}{ OF CONSTITUENTS IN GRAMS. } \\
\hline & & $\begin{array}{c}\text { Path. A, } \\
\text { 50 yrs. } \\
\text { (6) }\end{array}$ & $\begin{array}{c}\text { Normal, } \\
67 \text { yrs. } \\
\text { (22) }\end{array}$ & $\begin{array}{l}\text { Normal, } \\
35 \text { yrs.' } \\
(3)\end{array}$ & $\begin{array}{l}\text { Normal, } \\
\text { 33 yrs. } \\
\text { (28) }\end{array}$ \\
\hline Brain .... & 1309.6 & I 199.5 & 1297.9 & 1158.3 & 1221.3 \\
\hline Cerebrum ......... & 1091.0 & 1037.2 & 1075.0 & 986.0 & 1026.0 \\
\hline Water $\ldots \ldots \ldots \ldots$. & .834 .7 & 811.7 & 843.6 & 718.3 & 790.7 \\
\hline$\ldots \ldots \ldots \ldots$ & . 256.3 & 225.5 & 231.5 & 267.7 & 235.3 \\
\hline Phosphatids ... & 52.80 & 51.45 & 70.33 & 67.64 & 61.56 \\
\hline Cerebrosides & 4.80 & 7.78 & 18.49 & 25.44 & 13.13 \\
\hline Sulphatids ..... & II.24 & 7.79 & 14.52 & I6.96 & 6.77 \\
\hline Cholesterol & - 54.55 & 46.88 & 27.42 & 40.24 & 49.34 \\
\hline Total lipins.... & . 123.39 & I 3.88 & 130.60 & 150.20 & 130.80 \\
\hline Total proteins........ & . 96.12 & 80.90 & 80.97 & 88.65 & 83.20 \\
\hline Org. extractives. & - 22.80 & 17.63 & 9.46 & 20.02 & II.39 \\
\hline Inorg. extractives. & . 14.07 & 13.07 & 10.32 & 8.97 & 9.85 \\
\hline Total extractives.... & - $\quad 36.87$ & 30.70 & 19.78 & 28.99 & 21.24 \\
\hline Lipin sulphur.... & .229 & .156 & .290 & .335 & .133 \\
\hline Protein sulphur.. & .764 & .726 & .656 & .385 & .533 \\
\hline Neutral sulphur.. & .153 & .156 & $.16 \mathrm{I}$ & .217 & .072 \\
\hline Inorg. sulphur... & .087 & .062 & .032 & .088 & .031 \\
\hline Total sulphur........ & 1.233 & 1.100 & 1.140 & 1.025 & .770 \\
\hline Lipin phospl & 2.269 & 2.147 & $2.73 \mathrm{I}$ & 2.958 & 2.401 \\
\hline phos..... & .153 & .114 & .129 & .138 & .113 \\
\hline Org. phosphorus. & .851 & .643 & .086 & .483 & .277 \\
\hline Inorg. phosphorus & .404 & .508 & .570 & .473 & .934 \\
\hline Total phosphorus.... & 3.677 & $3.4^{12}$ & 3.516 & 4.052 & 3.724 \\
\hline
\end{tabular}

CONSTITUENTS IN PERCENTAGES OF FRESH TISSUE.

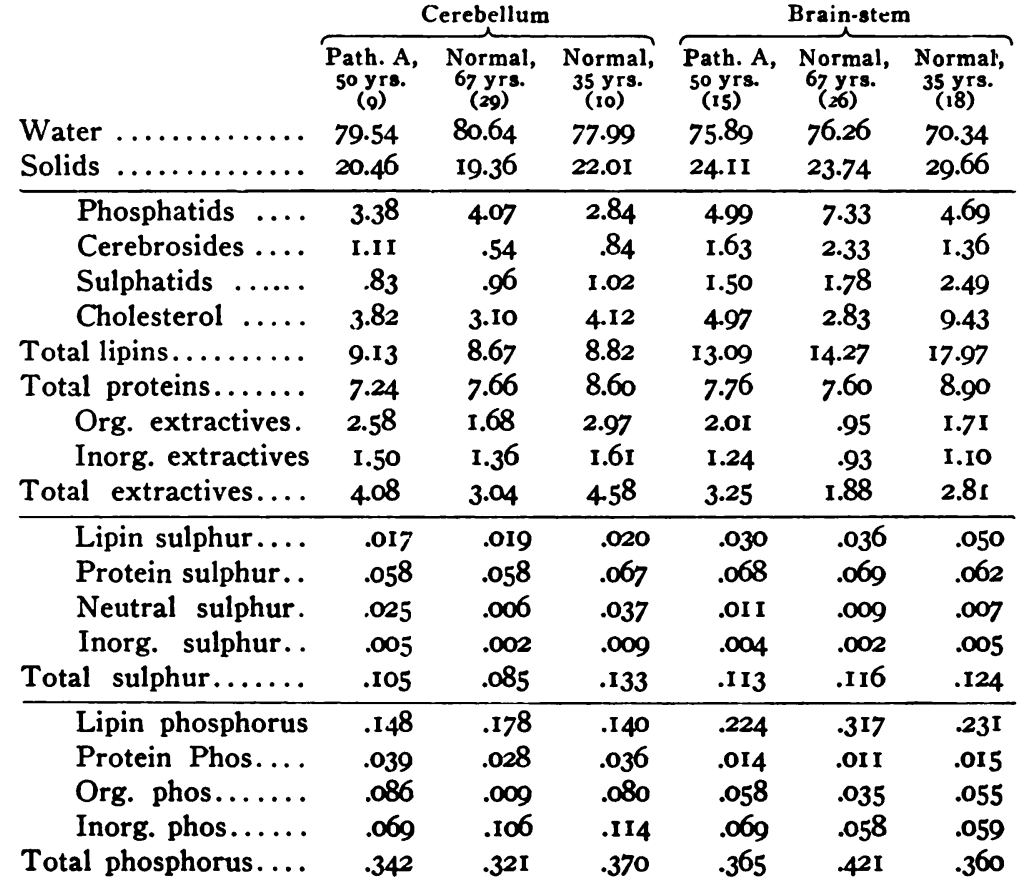


CONSTITUENTS IN PERCENTAGES OF SOLIDS.

\begin{tabular}{|c|c|c|c|c|c|c|}
\hline & \multicolumn{3}{|c|}{ Cerebellum } & \multicolumn{3}{|c|}{ Brain-stem } \\
\hline & $\begin{array}{l}\text { Path. A, } \\
\text { 50 yrs. } \\
\text { (g) }\end{array}$ & $\begin{array}{c}\text { Normal, } \\
67 \text { yrs. } \\
\text { (29) }\end{array}$ & $\begin{array}{c}\text { Normal, } \\
35 \text { yrs. } \\
\text { (10) }\end{array}$ & $\begin{array}{c}\text { Path. A, } \\
\text { 5o yra } \\
\text { (15) }\end{array}$ & $\begin{array}{l}\text { Normal, } \\
67 \text { yrs. } \\
\text { (26) }\end{array}$ & $\begin{array}{c}\text { Normal, } \\
\text { 35 yrs." } \\
\text { (18) }\end{array}$ \\
\hline Phosphatids .... & 16.49 & 21.00 & 12.90 & 20.72 & 30.86 & 15.73 \\
\hline Cerebrosides ... & $5.4 \mathrm{I}$ & 2.77 & 3.81 & 6.75 & 9.83 & 4.58 \\
\hline Sulphatids .... & 4.07 & 4.98 & 464 & 6.15 & 7.52 & 8.40 \\
\hline Cholesterol ..... & 18.65 & I6.05 & 18.72 & 20.65 & I I. 87 & 31.86 \\
\hline Total lipins......... & 44.62 & 44.70 & 40.07 & 54.27 & 60.08 & 60.57 \\
\hline Total proteins....... & 35.43 & 39.51 & 39.12 & 32.24 & 32.01 & 29.96 \\
\hline Org. extractives. & 12.64 & 8.68 & 13.51 & 8.36 & 4.01 & 5.78 \\
\hline Inorg. extractives & 7.31 & 7.01 & 7.30 & 5.13 & 3.90 & 3.69 \\
\hline Total extractives.... & 19.95 & 15.69 & 20.91 & 13.49 & 7.91 & 9.47 \\
\hline Lipin sulphur... & .081 & .100 & .093 & .123 & .150 & .168 \\
\hline Protein sulphur. & $.28 \mathrm{I}$ & .296 & .307 & .281 & .289 & .211 \\
\hline Neutral sulphur. & .124 & .032 & .168 & .045 & .037 & .023 \\
\hline Inorg. sulphur. .. & .023 &.$\infty 09$ & .044 & .018 & .009 & .018 \\
\hline Total sulphur...... & .509 & .437 & .612 & .467 & .485 & .420 \\
\hline Lipin phosphorus & .721 & .912 & .642 & .926 & I.343 & .778 \\
\hline Protein phos..... & .192 & .146 & .163 & .059 & .044 & .052 \\
\hline Org. phosphorus. & .417 & .046 & .364 & .242 & .147 & .184 \\
\hline Inorg. phos...... & .335 & .546 & .522 & .285 & .238 & 199 \\
\hline Total phosphorus.... & 1.665 & 1.650 & 1.691 & 1.512 & 1.772 & 1.213 \\
\hline
\end{tabular}

WEIGHT OF CONSTITUENTS IN GRAMS.

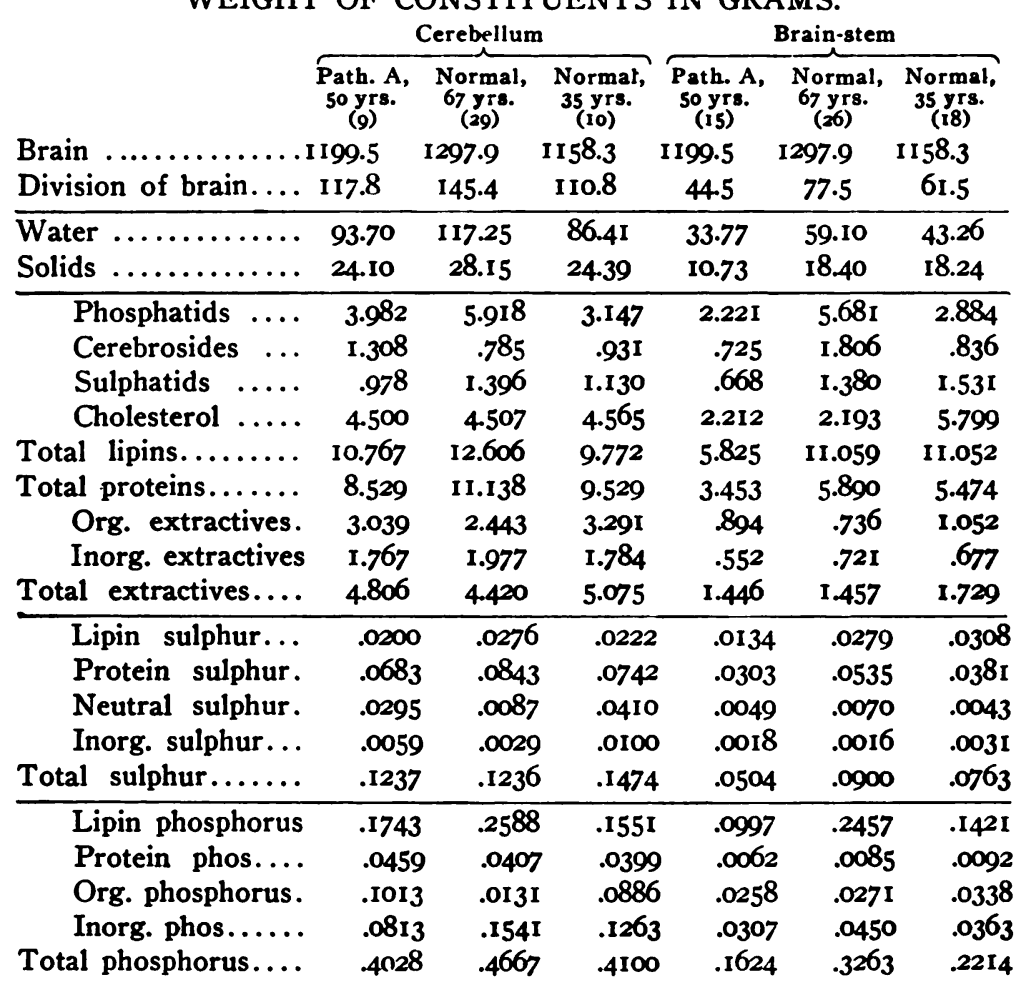




\section{Discussion of Results.}

The variations in normal material are rather large, so it is necessary to exercise some restraint in considering differences between normal and pathological as significant. However, there are changes, as the data show, for which no variations in normal nor errors in analyses could account. It seemed wise to indicate not only the certain evidences of alteration, but to point out, also, those that may have some importance.

CEREBRUM.

Water and Total Solids.-Though the pathological cerebrums had a slightly greater average percentage amount of water, the difference was so small that it could well come within the limits of variability. One might expect an increased amount of water to take the place of any constituents that had degenerated and were removed. In fact, an increase in water content is supposed to be a measure of the extent of the pathological condition.". ". With the loss of a part of some one or more brain constituents a decrease in total solids should follow; the data indicates but a small decrease, if any. That there are definite changes in the cerebrum, is certain. How, then, account for so little change in total solids?

In the first place, the substance showing a decrease may be changed into some degeneration product, but not be removed from the tissue. In this case some other fraction should show an absolute and a percentage increase. The data bring out this as a significant factor.

In the second place, the amount of the substance altered may be a rather large percentage amount of that particular substance, but it may be actually so small as to be within the limits of variability in the total amount of solids.

Lipins.-It is in this group that the most interesting changes have occurred in the cerebrum. There has been an average loss of 14 per cent of the total lipins. Though the proteins are supposed to be more directly related to vital activity, it is the lipins that are primarily affected in this degeneration. The phosphatids (lipoid P.) show in both cases rather marked decrease., 4, 5, 8, There is approximately I 5 per cent less than in normal cerebrum. 
This is true of the absolute amounts, as well as percentage amounts, in both moist and dry tissue.

Of all the constituents of the cerebrum, the cerebrosides show the most marked decrease ( 50 to 75 per cent). Other pathological conditions have shown large loss of these constituents. $", \cdot$ These are the last constituents to be laid down by the nerve to form its sheath. It is usually assumed that the substances that are last to form in development are the first to go. This seems to be true of the cerebrosides, though we think of them as rather stable substances that are thrown off as a product of the metabolic activity of the nerve.

Though there seems to be a close relationship between the cerebrosides and sulphatids (lipoid sulphur) chemically and physiologically, the latter compounds do not show such conspicuous losses. If the medullary sheath is largely affected in paresis, one would expect decrease in this group. In several of the brain diseases this lipolytic action on the medullary sheath is the predominating degenerative change.

The cholesterol data are not very reliable because they sum up the errors in the other lipin figures, and they include other substances of fat-like nature besides cholesterol. Nevertheless, the figures indicate that cholesterol shows an increase in percentage of the solids and probably in absolute quantity. $4,3,0$ If there is such an increase in actual number of grams, cholesterol must have been synthesized in the degenerating tissue. However, it may be that it is only the percentage of solids that has increased. In this case the easiest interpretation is that the cholesterol has been left behind while other compounds have been removed. The chief obstacle to this interpretation is that there really has not been very much, if any, loss of solids.

Proteins.-There may be a slight increase in total protein, but it is at most very slight. There are some indications, however, that the distribution of proteins is somewhat altered. Protein sulphur is supposed to be largely associated with neurokeratin, so it is probable that the percentage amount of neurokeratin has increased slightly because of the removal of other substances in the medullary sheath from this more stable, supporting substance. The nucleoproteins, as judged by the protein phosphorus, have changed but little." ${ }^{1}$ This may mean that in this disease the 
functioning protoplasm, both that in nucleus and that in the cytoplasm, is but little altered.

Extractives.-The total extractives show very important increases in the pathological cases (about 30 per cent).., For some reason the retention of these rather simple compounds takes place, making the resemblance to young cells suggestive. Many of the facts in this paper superficially indicate a rejuvenescence during degeneration. Though there is an increase in the inorganic as well as in the organic constituents of this group, the changes in the latter are much more pronounced. (The separation into these two divisions is very rough.) Neutral sulphur,, , ' which is supposed to be related to the oxidative efficiency of the cells, may be slightly decreased. If this is true, it is contrary to what one would expect in a rejuvenated tissue. Organic phosphorus, which is present probably as a partly decomposed phosphatid molecule, is markedly increased.

\section{CEREBELLUM AND BRAIN-STEM.}

The cerebellum and brain-stem of but one of the brains were analyzed. Since this was the one which developed bulbar paralysis, one might not be surprised if the medullar midbrain portion showed some degeneration; but the degeneration was not as pronounced as in the cerebrum. For certain reasons the variations in these portions were large, thus making it difficult to select the significant figures. Water and total solids in both divisions seem to be nearly normal.

Lipins.- Neither in total lipins nor in any particular lipin does the cerebellum show any abnormality. The midbrain, medulla, pons region shows a loss of lipins. It is difficult to be sure which ones are involved in this loss, probably as in the cerebrum the phosphatids and the cerebrosides principally.

The total proteins may be slightly increased in the brain-stem. Neurokeratin, as shown by protein sulphur, has changed but little. The differences between normal nucleoprotein (protein P.) and pathological indicate a small increase in the latter. In the cerebellum there is less total protein than in normal, and more nucleoprotein; but these are probably due to individual variations that have no pathological significance.

Extractives.-Here again the cerebellum gives no evidence of abnormality, while the brain-stem shows marked increase in both 
organic and inorganic extractives. Neutral sulphur has increased, as has both organic and inorganic phosphorus.

\section{Conclusions and Summary.}

The principal changes in the cerebrum of the case of paresis ("Path. K.") were in the lipins and extractives. The substances (cerebrosides) associated most closely with sheath development showed largest losses. The phosphatids and sulphatids are present in smaller amounts than in normal cerebra. Both organic and inorganic extractives show maked increases in percentage and absolute amounts. This is to be expected in degenerative changes, if it is the more complex structure substances that alter to simpler compounds which are but partly removed from the tissue.

The changes in the cerebrum in the case of organic brain disease ("Path. A.") (probably bulbar paralysis) which gave a syphilitic history show essentially the same kind of change as the case above; but all were less marked. This would suggest that the alterations were due to the action of spirochætes. The midbrain, medulla, and pons exhibited about the same kind of chemical changes as the cerebrum. The cerebrosides, sulphatids and phosphatids, and therefore total lipins, showed distinct losses. The proteins, water and total solids were nearly normal ; but both organic and inorganic extractives were high. Though the data for the cerebellum show variations, they are not supposed to be of pathological significance.

\section{LITERATURE.}

I. Mott, F. W.: Amaurotic Dementia. Arch. Neur., III, 218 (1907).

2. Koch, W., and Mann, S. A.: Dementia Precox and General Paralysis. Arch. Neur. and Psych. (I909) IV.

3. Donaldson, H. H.: J. Neur. and Psych., 20, 119 (1910).

4. Smith, L., and Mair, J.: General Paralysis. Path. and Bact., 16, 131 (19II).

5. Carbone and Pighini, G.: General Paralysis. Biochem. Z., 46, 450 (1912).

6. Bornstein, A.: Dementia Precox. Münch. med. Woch., 1994 (1913).

7. Pighini, G.: General Paralysis. Biochem. Z., 62, 317 (1914).

8. Carbone and Pighini, G.: General Paralysis. Biochem. Z., 63, 304 (1914).

9. Koch, M. L., and Voegtlin, C.: Pellagra. Hygienic Bulletin, 103 (1916). 